\title{
Editorial
}

\section{Parafrasa: reword everything into your own words!}

Format tulisan yang sering dijadikan latihan menulis tulisan ilmiah seringkali berbentuk "Tinjauan Pustaka.” Hampir semua dokter yang menjalani pendidikan spesialis menyelesaikan pendidikannya melalui penyelesaian tugas menulis yang di antaranya berformat tinjauan pustaka. Namun lebih dari sekedar "hanya tinjauan pustaka," pada galibnya format tinjauan pustaka selalu ada di dalam sebuah usulan penelitian yang merupakan sebuah studi mendalam tentang suatu masalah yang sedang menjadi topik penelitian. Studi yang mendalam tersebut sebaiknya merupakan sebuah kajian literatur yang menghasilkan buah pemikiran kritis yang selanjutnya merupakan sebuah landasan untuk menyusun pertanyaan penelitian beserta hipotesisnya.

Sayangnya, penulisan tinjauan pustaka seringkali disertai dengan cara menyitir ungkapan orang lain atau tulisan diri sendiri (yang sudah dipublikasi) yang tidak menunjukkan pemahaman yang benar. Seluruh kalimat atau bahkan paragraf dikopi sama persis dengan aslinya. Sebenarnya pengungkapan dengan gaya copy and paste tersebut tidak dibenarkan dalam etika menulis karya ilmiah. Setiap penulis harus belajar untuk mengungkapkan pemahaman yang diperoleh dari tulisan lain dengan gaya bahasa sendiri. Ungkapan yang menggunakan kata-kata dan kalimat sendiri tersebut tentu saja tidak boleh bertentangan bila memang tidak dimaksudkan untuk menyampaikan pertentangan ide. Akan tetapi, penulisan dengan gaya copy and paste tersebut tetap memiliki ruang dalam tulisan ilmiah yaitu bila kita tidak ingin mengubah kalimat atau frasa tulisan rujukan sesuai dengan aslinya. Syarat penulisan yang terakhir ini adalah dengan memberikan tanda petik di awal dan akhir kutipan.

Berikut ini adalah contoh sitiran dengan menggunakan pengungkapan yang berbeda dengan kutipan aslinya. The wide range of skin colors - from the deepest chocolate brown of Africa's Ivory Coast to the warm olives of the Mediterranean to the pale fairness of Scandinavia - is paralleled by a similarly wide array of cultural beliefs... ${ }^{1}$ Tulisan yang memberikan keterangan adanya perbedaan warna kulit yang tergantung kepada ras dan lokasi geografis dapat dicerna dan selanjutnya diungkapkan dengan gaya bahasa sendiri. Misalnya: Skin color varies among different races and geographic regions. People from Africa's Ivory Coast have deepest chocolate brown colored skin, while those from Mediterranean have warm olives skin; and Scandinavians pale fairness skin. ... Contoh lain: "Hippocrates mendefinisikan ganglion yang diambil dari bahasa Yunani sebagai masses that contain mucoid flesh. Ganglion yang merupakan benjolan jaringan lunak tersering pada hand masih menjadi topik yang menimbulkan perdebatan, baik tentang etiologi maupun tata laksananya". ${ }^{2}$ Pengungkapan sitiran dalam merujuk tulisan tersebut dapat disampaikan dengan gaya bahasa sendiri tanpa mengubah maknanya: "Istilah ganglion yang diambil dari bahasa Yunani didefinisikan oleh Hippocrates sebagai masses that contain mucoid flesh. Etiologi dan tatalaksana ganglion yang merupakan benjolan jaringan lunak tersering pada tangan masih kontroversial."

Cara penyampaian kutipan yang menggunakan kata-kata dan kalimat-kalimat sendiri tersebut merupakan upaya melakukan parafrasa. Parafrasa dalam Kamus Besar Bahasa Indonesia Edisi Keempat yang dikeluarkan oleh Pusat Bahasa Departemen Pendidikan Nasional pada tahun 2008 didefinisikan sebagai "pengungkapan kembali suatu tuturan dari sebuah tingkatan atau macam bahasa menjadi tuturan yang lain tanpa mengubah pengertian;" atau "penguraian kembali suatu teks (karangan) dalam bentuk (susunan kata-kata) yang lain, dengan maksud untuk dapat menjelaskan makna yang tersembunyi". ${ }^{3}$ Dengan demikian memparafrasakan berarti "menguraikan kembali suatu teks dalam bentuk lain". ${ }^{3}$ Karena kutipan yang diambil dari Kamus Besar Bahasa Indonesia tersebut ditulis sama persis dengan aslinya, maka kutipan tersebut disertai dengan tanda petik.

\section{Daftar Pustaka}

1. P\&G Beauty \& Grooming. Defining issues, changing the tone of skin science. Available from: http://www.pgbeautyscience. com/defining-issues-skintone.html

2. Prasetyono TOH. Ganglion dan Hippocrates. J I Bedah Indones. 2005: 33(1): vii-viii. (Editorial)

3. Tim Redaksi Kamus Besar Bahasa Indonesia Pusat Bahasa. Kamus besar bahasa Indonesia Pusat Bahasa. $4^{\text {th }}$ ed. Jakarta: PT Gramedia Pustaka Utama; 2008.

Teddy O.H. Prasetyono Divisi Bedah Plastik Departemen Bedah FKUI/ RS Cipto Mangunkusumo, Jakarta Email: teddyohprasetyono@yahoo.com 